\title{
Faktor- Faktor yang Mempengaruhi Permintaan Daging Ayam Kampung di Pasar Tradisional Kota Surakarta
}

\author{
D. P. Amelia*, S. H. Pusrnomo, Sudiyono \\ Program Studi Peternakan, Fakultas Pertanian, Universitas Sebelas Maret
}

\begin{abstract}
ABSTRAK
Penelitian ini bertujuan untuk mengetahui faktor-faktor yang berpengaruh terhadap permintaan daging ayam kampung dan untuk mengetahui perbedaan permintaan antar kelompok konsumen berdasarkan karakteristik demografis konsumen terhadap pembelian daging ayam kampung di pasar tradsisional Kota Surakarta.Penelitian ini dilaksanakan pada tanggal 24 Agustus -21 September 2017 di pasar tradisional Kota Surakarta dengan metode survei.Responden adalah pembeli daging ayam kampung dengan pemilihan sampel menggunakan metode convenience sampling sebanyak 60 responden. Data yang diperoleh berupa data primer meliputi: karakteristik demografis, (pendapatan, umur, pendidikan, jumlah anggota keluarga), harga daging ayam kampung dan harga daging ayam broiler. Data sekunder meliputi data Dinas Peternakan, Badan Pusat Statistik, dan buku pustaka.Analisis data yang digunakan adalah analisis regresi linier berganda dilanjutkan dengan uji determinasi $\left(\mathrm{R}^{2}\right)$, uji $\mathrm{F}$, uji $\mathrm{t}$ dan uji Oneway Anova. Analisis regresi linier berganda diperoleh persamaan $\mathrm{Y}=4,811-$ $2,443 \mathrm{X}_{1^{-}}-4,366 \mathrm{X}_{2^{-}} \quad 0,038 \mathrm{X}_{3}+5,503 \mathrm{X}_{4^{-}} \quad 0,248 \mathrm{X}_{5^{-}} \quad 0,197 \mathrm{X}_{6}$. Nilai $\mathrm{R}^{2}$ sebesar 0,593 artinya semua variabel bebas mempengaruhi variabel terikat yaitu permintaan daging ayam kampung sebesar 59,3\%. Uji $F$ menunjukkan nilai $F_{\text {hitung }}$ $12,876>\mathrm{F}_{\text {tabel }} 2,275$ berarti bahwa menolak $\mathrm{H}_{0}$ yaitu variabel bebas berpengaruh secara bersama-sama terhadap variabel terikat.Hasil Uji t dan hasil uji Oneway Anova variabel umur dan pendapatan secara individu berbengaruh signifikan terhadap permintaan daging ayam kampung.Kesimpulan dari penelitian ini adalah semua variabel secara bersama-sama mempengaruhi permintaan daging ayam kampung, secara individu faktor umur dan pendapatan, menunjukkan perbedaan terhadap permintaan daging ayam kampungdi pasar tradisional Kota Surakarta.
\end{abstract}

Kata Kunci: Permintaan, Daging ayam kampung, Pasar tradisional

\section{Factors Affecting the Demand for Free-Range Chicken Meat in Traditional Markets in Surakarta City}

\section{ABSTRACT}

This research aimed to find out the factors affecting the demand for free-range chicken meat among consumers and to find out the difference of demand between one consumer group and another by demographic characteristics of consumers in traditional markets of Surakarta City. This research was conducted from August 24 to September 21, 2017 in traditional markets of Surakarta City using survey method. This study was a descriptive and associative research. Respondents were 60 (sixty) buyers of free-range chicken meat selected using convenience sampling method. The data obtained consisted of primary and secondary ones. Primary data included demographic characteristics (income, age, education, and family member number), free-range chicken meat price, and broiler chicken meat price. Secondary data included data from Animal Husbandry Service, Central Statistic Bureau, and literature. Data analysis was carried out using a multiple linear regression analysis, followed with determinacy test $\left(R^{2}\right), F$ test, $t$-test and One-way Anova test. From the multiple linear regression analysis, the following equation was obtained $=Y=4.811-2.443 X_{1^{-}} 4.366 X_{2^{-}} 0.038 X_{3}+5.503 X_{4^{-}} 0.248 X_{5^{-}} 0.197 X_{6}+1.518$. $R^{2}$ value was 0.593, meaning that all independent variables affected dependent variable (demand for free-range chicken meat) by $59.3 \%$. The result of Ftest showed $F_{\text {statistic }} 12.876>F_{\text {table }} 2.275$, meaning that $H_{0}$ was not supported, indicating that independent variables affected simultaneously the dependent one. The result of t test and One-way Anova test showed that age and income partially (individually) affected significantly the demand for free-range chicken meat. The conclusion of research was that all variables affected simultaneously the demand for free-range chicken meat, and age and income factors individually showed the difference of demand for free-range chicken meat in traditional market of Surakarta City.

Keywords: Demand, Free-range chicken meat, Traditional market

\section{PENDAHULUAN}

Kebutuhan pangan merupakan kebutuhan pokok manusia yang harus dipenuhi. Kebutuhan pangan tersebut diantaranya berasal dari produk pangan asal hewani. Protein hewani sangat dibutuhkan bagi peningkatan kualitas sumber daya manusia. Protein

*Penulis Korespondensi: Digna Puspa Amelia

Alamat: J1. Ir. Sutami 36A Kentingan, Surakarta, Jawa Tengah

E-mail: Digna.2095@gmail.com hewani banyak terdapat pada makanan seperti telur, daging, susu, ikan dan unggas. Salah satu daging ternak yang mudah diperoleh adalah daging ayam. Daging ayam kampung merupakan salah satu daging yang banyak dikonsumsi oleh masyarakat baik dalam bentuk daging maupun hasil olahannya. Menurut Triyanti (2000) daging ayam kampung memegang peranan cukup penting dalam pemenuhan kebutuhan gizi masyarakat, karena banyak mengandung protein dan zat-zat lainnya seperti lemak, mineral, vitamin yang penting untuk kelancaran proses metabolisme di 
dalam tubuh. Daging ayam kampung memiliki rasa enak, aroma khas dan rendah kandungan lemak.

Kota Surakarta dengan luas wilayah $44,04 \mathrm{~km}^{2}$ didiami penduduk sebanyak 512.226 jiwa, terdiri dari 249.113 laki-laki dan 263.113 jiwa perempuan (Badan Pusat Statistik Kota Surakarta, 2016). Tentu saja terdapat perbedaan konsumen untuk membeli kebutuhan mereka di pasar tradisional. Menurut Suyanto dan Nurhadi (2004) pola konsumsi dipengaruhi oleh sejumlah faktor yaitu: usia, jenis kelamin, tingkat pendidikan, jumlah anggota keluarga, pendapatan, agama, lingkungan tempat tinggal dan gaya hidup. Pemenuhan kebutuhan daging di Surakarta diambil dari beberapa jenis daging seperti: daging sapi, daging kambing, daging ayam broiler maupun daging ayam kampung.

Penelitian ini bertujuan untuk mengetahui faktor- faktor yang berpengaruh terhadap permintaan daging ayam kampung pada konsumendan mengetahui perbedaan permintaan antar kelompok konsumen satu dengan kelompok konsumen yang lainnya berdasarkan karakteristik demografis konsumen di Pasar Tradisional Kota Surakarta.

\section{MATERI DAN METODE}

Penelitian ini dilaksanakan pada tanggal 24 Agustus - 21 September 2017 di enam pasar tradisional yaitu Pasar Legi, Pasar Gede, Pasar Nusukan, Pasar Kliwon, Pasar Mojosongo, Pasar Jebresyang terletak di Kota Surakarta. Jenis penelitian ini adalah penelitian deskriptif dan asosiatif. Penelitian ini menggunakan metode survei dalam pengambilan data. Penelitian dibagi menjadi dua tahap yaitu prasurvei dan survei. Pra survei dilaksanakan untuk menentukan lokasi pengambilan data. Tahap survei dilaksanakan untuk proses pengambilan data primer. Pengambilan lokasi penelitian dilakukan secara purposive sampling, yaitu pengambilan lokasi dengan sengaja dengan pertimbangan letak geografis pasar, kemampuan jangkauan peneliti dan adanya penjual daging ayam kampung di pasar tersebut. Letak geografis ditentukan berdasarkan lokasi pasar (utara, timur, selatan, barat) di Kota Surakarta dengan tujuan untuk mewakili populasi dalam proses pengambilan data. Teknik pengambilan responden yang akan digunakan secara convenience sampling yaitu dipilih berdasarkan kemudahan. Penentuan jumlah sampel responden apabila melakukan analisa dengan regresi jumlah anggota sampel minimal 10 kali jumlah variabel yang diteliti (Sugiyono, 2009). Jumlah responden yang akan digunakan dalam penelitian ini sebanyak $(10 \times$ variabel penelitian $=10 \times 6=60$ responden).

\section{Analisis Data}

Analisis data dengan menggunakan software SPSS 22 for windows. Analisis deskriptif merupakan metode penelitian dengan cara mengumpulkan data- data sesuai dengan yang sebenarnya kemudian datadata tersebut disusun, diolah dan dianalisis untuk dapat memberikan gambaran mengenai masalah yang ada (Sugiyono, 2009). Analisis regresi linier berganda digunakan untuk mengetahui pengaruh umur, pendapatan, pendidikan, jumlah anggota keluarga, harga daging ayam kampung, harga daging ayam broiler terhadap permintaan daging ayam kampung. Uji model statistik dengan koefisien determinasi (Uji $\mathrm{R}^{2}$ ) untuk melihat seberapa kuat variabel yang dimasukkan kedalam model dapat menerangkan model. Uji F untuk mengetahui variabel independen atau bebas secara bersama-sama mempengaruhi variabel dependen atau terikat pada tingkat signifikasi 5\% (0,05) (Ghozali, 2013). Uji t untuk mengetahui apakah variabel bebas (tingkat pendapatan, jumlah anggota keluarga, tingkat pendidikan, tingkat umur, harga barang sustitusi dan harga daging ayam kampung) yang digunakan secara parsial berpengaruh nyata terhadap variabel tak bebas (permintaan daging ayam kampung) pada tingkat signifikan $(\alpha)=5$ persen. Uji Anova atau uji beda digunakan untuk menganalisis permintaan konsumen terhadap daging ayam kampung pada pasar tradisional.

\section{HASIL DAN PEMBAHASAN}

\section{Keadaan Umum Daerah Penelitian}

Kota Surakarta terletak antara $110^{\circ} 45^{\prime} 15^{\prime}$ 'dan $110^{\circ} 45^{\prime} 35^{\prime \prime}$ Bujur Timur dan antara $7^{\circ} 36^{\prime}$ dan $7^{\circ} 56^{\prime}$ Lintang Selatan. Wilayah Kota Surakarta atau lebih dikenal dengan "Kota Solo" merupakan dataran rendah dengan ketinggian $\pm 92 \mathrm{~m}$ dari permukaan laut. Kota Solo berbatasan di sebelah utara dengan Kabupaten Boyolali, sebelah timur dengan Kabupaten Karanganyar, sebelah selatan dengan Kabupaten Sukoharjo dan di sebelah Barat dengan Kabupaten Sukoharjo. Luas wilayah Kota Surakarta mencapai $44,04 \mathrm{~km}^{2}$ yang terbagi dalam 5 kecamatan, yaitu : Kecamatan Laweyan, Serengan, Pasar kliwon, Jebres dan Banjarsari. Menurut Badan Pusat Statistik tahun 2016 Kota Surakarta didiami penduduk sebanyak 512.226 jiwa, terdiri dari 249.113 laki-laki dan 263.113 perempuan.

\section{Karakteristik Responden}

Responden dalam penelitian ini adalah konsumen daging ayam kampung yang berada di pasar tradisional Kota Surakarta.Responden memiliki karakteristik yang beragam. Karakteristik responden dapat dilihat pada Tabel 1 .

Berdasarkan Tabel 1. umur responden tertinggi pada rentang umur 46-55 tahun sebanyak 15 orang $(25,00 \%)$. Berdasarkan data diatas, umur $<20$ tahun memang kurang begitu produktif untuk memenuhi kebutuhan sehari-hari seperti berbelanja kebutuhan pokok. Mereka masih disibukkan dengan segala macam aktivitas yang menyita waktu mereka seperti sekolah dan kegiatan lainnya. Umur $>55$ tahun, juga mempunyai jumlah sedikit karena diumur ini manusia 
Tabel 1. Karakteristik Responden

\begin{tabular}{|c|c|c|c|}
\hline No. & Karakteristik Demografis & Jumlah (Orang) & Persentase \\
\hline \multirow[t]{6}{*}{1} & Umur (tahun) & & \\
\hline & $<20$ & 8 & 13,30 \\
\hline & $26-35$ & 13 & 21,70 \\
\hline & $36-45$ & 13 & 21,70 \\
\hline & $46-55$ & 15 & 25,00 \\
\hline & $>55$ & 11 & 18,30 \\
\hline \multirow[t]{5}{*}{2.} & Tingkat Pendapatan (Rp) & & \\
\hline & $500.000-1.000 .000$ & 13 & 21,70 \\
\hline & $1.000 .000-2.000 .000$ & 10 & 16,70 \\
\hline & $2.000 .000-3.000 .000$ & 26 & 43,30 \\
\hline & $>3.000 .000$ & 11 & 18,30 \\
\hline \multirow[t]{6}{*}{3.} & Tingkat Pendidikan & & \\
\hline & Sekolah Dasar & 13 & 21,70 \\
\hline & Sekolah Menengah Pertama & 21 & 35,00 \\
\hline & Sekolah Menengah Atas & 18 & 30,00 \\
\hline & Diploma & 5 & 8,30 \\
\hline & Sarjana & 3 & 5,00 \\
\hline \multirow[t]{5}{*}{4.} & Jumlah anggota keluarga & & \\
\hline & 1 & 2 & 3,30 \\
\hline & $2-3$ & 22 & 36,70 \\
\hline & $4-5$ & 30 & 50,00 \\
\hline & $>6$ & 6 & 10,00 \\
\hline
\end{tabular}

Sumber: Data Primer Terolah, 2017

mengalami perubahan-perubahan fisik dengan ditandai dengan penurunan fungsi anggota tubuh.

Tingkat pendapatan responden terbanyak yaitu pada pendapatan $\mathrm{Rp} 2.000 .000,00$ - Rp 3.000.000,00 sebanyak 26 orang $(43,30 \%)$. Hal ini terjadi karena konsumen dengan tingkat pendapatan tinggi lebih memilih berbelanja dipasar yang sudah modern daripada di pasar tradisional karena mereka mencari kenyamana dalam berbelanja.

Tingkat pendidikan terbanyak responden adalah Sekolah Menengah Pertama yaitu 21 orang (35\%). Responden dengan tingkat pendidikan tinggi yaitu Diploma dan Sarjana hanya berjumlah sedikit karena mereka lebih memilih berbelanja di pasar modern seperti pasar swalayan karena lebih nyaman dan juga pasar modern memang disediakan untuk masyarakat golongan menengah keatas. Responden dengan pendidikan SMA, SMP, dan SD lebih banyak karena memang pasar tradisional disediakan untuk masyarakat golongan menengah kebawah. Hal ini sesuai dengan pendapat Suyanto (2004) yang mengatakan bahwa pasar tradisional adalah pasar yang dibangun oleh pemerintah, swasta, koperasi, atau swadaya masyarakat dengan tempat usaha berupa kios, toko, los, dan tenda dikelola oleh pedagang kecil, menengah dan koperasi dengan usaha skala kecil dan modal kecil dengan proses jual beli melalui tawar-menawar.

Jumlah anggota keluarga responden paling banyak adalah 4-5 orang yaitu 30 orang $(50,00 \%)$. Konsumen dengan jumlah anggota keluarga sedikit (1 orang) yaitu hanya sebanyak 2 orang saja dari keseluruhan jumlah responden atau $(3,3 \%)$, pasti akan sedikit pula dalam hal melakukan pembelian daging ayam kampung. Hal ini sesuai dengan pendapat Sumarwan (2003) bahwa semakin besar jumlah anggota keluarga semakin besar proporsi pengeluaran keluarga untuk makanan dari pada untuk bukan makanan. Ini berarti semakin kecil jumlah anggota keluarga, semakin kecil pula bagian pendapatan untuk kebutuhan makanan. Selebihnya, keluarga akan mengalokasikan sisa pendapatannya untuk konsumsi

Tabel 2. Harga Daging Ayam Kampung dan Harga Daging Ayam Broiler di Pasar Tradisional Kota Surakarta

\begin{tabular}{lcrr}
\hline \hline No. & Harga Daging & Jumlah (Orang) & Persentase \\
\hline $1 . \quad$ Harga daging ayam kampung $(\mathrm{Rp} / \mathrm{kg})$ & 22 & 36,30 \\
& $\leq 40.000-50.000$ & 5 & 8,30 \\
& $50.000-60.000$ & 29 & 48,30 \\
$60.000-70.000$ & 4 & 6,70 \\
$>70.000$ & & 0,00 \\
2. & Harga daging ayam broiler (Rp/kg) & 0 & 90,00 \\
$10.000-20.000$ & 54 & 8,30 \\
& $20.000-30.000$ & 5 & 1,70 \\
\hline
\end{tabular}


Tabel 3. Variabel-variabel dalam penelitan

\begin{tabular}{lccc}
\hline \hline \multicolumn{1}{c}{ Variabel } & Koefisien Regresi & T hitung & $\begin{array}{c}\text { Prob. (sig t) } \\
\alpha=0,05\end{array}$ \\
\hline $\mathrm{X}_{1}$ (Harga daging ayam kampung) & $-2,443$ & $-1,277$ & 0,207 \\
$\mathrm{X}_{2}$ (Harga daging ayam broiler) & $-4,366$ & $-0,055$ & 0,956 \\
$\mathrm{X}_{3}$ (Umur) & $-0,038$ & $-2,240$ & 0,029 \\
$\mathrm{X}_{4}$ (Pendapatan) & 5,503 & 6,576 & 0,000 \\
$\mathrm{X}_{5}$ (Pendidikan) & $-0,248$ & $-1,288$ & 0,203 \\
$\mathrm{X}_{6}$ (Jumlah anggota keluarga) & $-0,197$ & $-1,214$ & 0,230 \\
Konstanta & 4,811 & \\
F hitung & 12,876 & & 0,000 \\
R Square (R ${ }^{2}$ ) & 0,593 & \\
\hline Variabel terikat = Y (Permintaan) & & \\
\hline
\end{tabular}

Sumber: Data Primer Terolah, 2017

bukan makanan.

Berdasarkan Tabel 2. harga daging ayam kampung yang paling diminati dengan harga $\mathrm{Rp}$ 60.000-70.000,00 yaitu sebanyak 29 oarang (48,30\%). Daging ayam kampung dijual berdasarkan dari umur pemotongan. Daging ayam kampung umur pemotongan 3 bulan dijual dengan harga $\mathrm{Rp}$ $60.000,00-R p 70.000,00$, dimana diusia ini ayam berukuran besar dan citarasa dagingnya juga enak. Daging ayam kampung dengan harga dibawah $\mathrm{Rp}$ $60.000,00$ memiliki ukuran yang lebih kecil.

Harga daging ayam broiler yang paling diminati dengan harga Rp 20.000-30.000,00 yaitu sebanyak 54 orang $(90,00 \%)$. Hal ini terjadi karena mayoritas penjual daging ayam broiler di pasar tradisional Kota Surakarta menjual daging dengan harga Rp 20.000,00- Rp 30.000,00. Tinggi rendahnya daging ayam broiler tidak akan mempengaruhi keputusan untuk membeli karena konsumen membutuhkan daging ayam broiler untuk kebutuhan sehari-hari mereka.

\section{Analisis Regresi}

Analisis data yang digunakan adalah regresi linier berganda pada fungsi permintaan dengan cara deskriptif. Variabel-variabel dalam penelitan ini dapat dilihat pada Tabel 3 dan diperoleh uji regresi linier berganda dengan persaman sebagai berikut:

$$
\mathrm{Y}=4,811-2,443 \mathrm{X}_{1}-4,366 \mathrm{X}_{2}-0,038 \mathrm{X}_{3}+
$$$$
5,503 X_{4}-0,248 X_{5}-0,197 X_{6}+1,518
$$

Nilai konstanta data permintaan daging ayam kampung sebesar 4,811. Nilai permintaan daging ayam kampung di pasar tradisional (Y) akan mengalami kenaikan sebesar 4,811 tanpa dipengaruhi variabel-variabel penentu permintaan (harga daging ayam kampung, harga daging ayam broiler, umur, pendapatan, pendidikan, jumlah anggota keluarga). Nilai koefisien regresi variabel harga daging ayam kampung $\left(\mathrm{X}_{1}\right)$ adalah -2,443 menunjukkan pengaruh yang diberikan negatif, setiap penambahan 1 satuan harga daging ayam kampung akan menurunkan permintaan daging ayam kampung sebesar 2,443 satuan.
Nilai koefisien regresi variabel harga daging ayam broiler $\left(\mathrm{X}_{2}\right)$ adalah $-4,366$ menunjukkan pengaruh yang diberikan negatif, artinya setiap penambahan 1 satuan harga daging ayam broiler akan menurunkan permintaan daging ayam kampung sebesar 4,366 satuan. Nilai koefisien regresi variabel umur $\left(\mathrm{X}_{3}\right)$ adalah -0,038 menunjukkan pengaruh yang diberikan negatif, artinya setiap penambahan 1 satuan umur akan menurunkan permintaan daging ayam kampung sebesar 0,038 satuan. Nilai koefisien regresi variabel pendapatan $\left(\mathrm{X}_{4}\right)$ adalah 5,503 menunjukkan pengaruh yang diberikan positif, artinya setiap 1 satuan pendapatan akan menaikkan permintaan daging ayam kampung sebesar 5,503 satuan.

Nilai koefisien regresi variabel pendidikan $\left(\mathrm{X}_{5}\right)$ adalah -0,248 menunjukkan pengaruh yang diberikan negatif, artinya setiap penambahan 1 satuan pendidikan akan menurunkan permintaan daging ayam kampung sebesar 0,248 satuan. Nilai koefisien regresi variabel jumlah anggota keluarga $\left(\mathrm{X}_{6}\right)$ adalah 0,197 menunjukkan pengaruh yang diberikan negatif, artinya setiap penambahan 1 satuan jumlah anggota keluarga akan menurunkan permintaan daging ayam kampung sebesar $-0,197$ satuan.

Hasil analisis regresi diperoleh nilai $\mathrm{R}^{2}$ (Koefisien determinasi) sebesar 0,593 artinya semua variabel bebas mempengaruhi variabel terikat yaitu permintaan daging ayam kampung sebesar 59,3\%. Sisanya sebesar 40,7\% dipengaruhi oleh variabel lain diluar variabel yang diteliti atau dimasukkan dalam kesalahan pengganggu.

\section{Uji F}

Berdasarkan Tabel 3. diperoleh nilai $F_{\text {hitung }}$ sebesar 12,876 dengan signifikasi 0,001 . Tingkat signifikansi $5 \%$ df $(n-k-1)=60-6-1=53$, maka diperoleh nilai $\mathrm{F}$ tabel sebesar 12,876, $\mathrm{F}_{\text {hitung }}>\mathrm{F}_{\text {tabel }}$ $(2,275)$ berarti bahwa menolak $\mathrm{H}_{0}$ yaitu variabel bebas (harga daging ayam kampung, harga daging ayam broiler, umur, pendapatan, pendidikan, jumlah anggota keluarga) berpengaruh secara bersama-sama terhadap variabel terikat (permintaan daging ayam kampung). 
Tabel 4. Uji Anova

\begin{tabular}{|c|c|c|c|c|}
\hline Variabel & Mean & Std.Deviation & $F$ & Sig \\
\hline \multicolumn{5}{|l|}{ Umur (X3) } \\
\hline 1. $<25$ tahun & 3,55 & 0,527 & 2,816 & 0,034 \\
\hline 2. 26-35 tahun & 3,35 & 0,497 & & \\
\hline 3. $36-45$ tahun & 3,07 & 0,493 & & \\
\hline 4. $46-55$ tahun & 3,07 & 0,267 & & \\
\hline 5. $>55$ tahun & 3,00 & 0,471 & & \\
\hline \multicolumn{5}{|l|}{ Pendapatan (X4) } \\
\hline 1. $500.000-1.000 .000$ & 2,92 & 0,277 & 4,971 & 0,004 \\
\hline 2. $1.000 .000-2.000 .000$ & 3,10 & 0,567 & & \\
\hline 3. $2.000 .000-3.000 .000$ & 3,20 & 0,408 & & \\
\hline 4. $>3.000 .000$ & 3,58 & 0,480 & & \\
\hline \multicolumn{5}{|l|}{ Pendidikan (X5) } \\
\hline 5. SD & 2,92 & 0,493 & 1,801 & 0,142 \\
\hline 6. SMP & 3,31 & 0,476 & & \\
\hline 7. SMA & 3,29 & 0,469 & & \\
\hline 8. Diploma & 3,20 & 0,447 & & \\
\hline 9. Sarjana & 3,00 & 0,000 & & \\
\hline \multicolumn{5}{|l|}{ Jumlah anggota } \\
\hline \multicolumn{5}{|l|}{ Keluarga (X6) } \\
\hline 1. 1 & 3,0 & 0,00 & 0,619 & 0,606 \\
\hline 2. $2-3$ & 3,27 & 0,63 & & \\
\hline 3. $4-5$ & 3,13 & 0,34 & & \\
\hline 4. $>6$ & 3,33 & 0,51 & & \\
\hline
\end{tabular}

Sumber: Data Primer Terolah, 2017

\section{Uji t}

Berdasarkan Tabel 3. diperoleh hasil bahwa variabel harga daging ayam kampung mempunyai hasil yang tidak signifikan terhadap permintaan daging ayam kampung, jika diukur pada tingkat kepercayaan yang ditunjukkan oleh nilai t-hitung $\left(\mathrm{X}_{1}\right)$ sebesar $-1,277<\mathrm{t}$-tabel yaitu sebesar 1,674 yang berarti $\mathrm{H}_{0}$ diterima. Disimpulkan bahwa harga daging ayam kampung $\left(\mathrm{X}_{1}\right)$ di pasar tradisional Kota Surakarta secara individu tidak berpengaruh pada tingkat kepercayaan $95 \%$ terhadap permintaan daging ayam kampung. Variabel harga daging ayam kampung tidak berpengaruh dalam permintaan daging ayam kampung. Hal ini disebabkan karena konsumen daging ayam kampung tidak memperdulikan harga dan hanya memperdulikan cita rasa. Harga daging ayam kampung yang mahal membuat konsumen tetap akan membeli daging ayam kampung.Hal ini sesuai dengan pendapat Triyanti (2000) ayam kampung sebenarnya lebih disukai oleh masyarakat kita karena lemaknya sedikit.

Variabel harga daging ayam broiler tidak berpengaruh nyata terhadap permintaan daging ayam kampung, jika diukur pada tingkat kepercayaan yang ditunjukkan oleh nilai t-hitung $\left(\mathrm{X}_{2}\right)$ sebesar $-0,055<\mathrm{t}-$ tabel yaitu sebesar 1,674 yang berarti $\mathrm{H}_{0}$ diterima dapat disimpulkan bahwa harga daging ayam broiler $\left(\mathrm{X}_{2}\right)$ di pasar tradisional Kota Surakarta secara individu tidak berpengaruh pada tingkat kepercayaan 95\% terhadap permintaan daging ayam kampung. Harga daging ayam broiler lebih murah dibandingkan dengan harga daging ayam kampung membuat konsumen lebih memilih untuk mengkonsumsi daging ayam broiler. Hal ini sesuai dengan pendapat Kasih et al. (2012), saat ini masyarakat Indonesia lebih banyak mengenal daging ayam broiler sebagai daging ayam potong yang biasa dikonsumsi karena kelebihan yang dimiliki seperti kandungan atau nilai gizi yang tinggi sehingga mampu memenuhi kebutuhan nutrisi dalam tubuh, dan mudah didapatkan di pasaran maupun supermarket dengan harga yang terjangkau.

Variabel umur berpengaruh terhadap permintaan daging ayam kampung, jika diukur pada tingkat kepercayaan yang ditunjukkan oleh nilai thitung $\left(\mathrm{X}_{3}\right)$ sebesar $-2,240>\mathrm{t}$-tabel yaitu sebesar 1,674 yang berarti $\mathrm{H}_{0}$ ditolak dapat disimpulkan bahwa harga daging ayam kampung $\left(\mathrm{X}_{3}\right)$ di pasar tradisional Kota Surakarta secara individu berpengaruh pada tingkat kepercayaan $95 \%$ terhadap permintaan daging ayam kampung. Variabel umur berpengaruh terhadap permintaan daging ayam kampung. Hal ini karena umur konsumen daging ayam kampung pada umumnya berusia produktif. Usia produktif memiliki tingkat konsumsi yang tinggi dalam memilih selera yang diinginkan terhadap pemilihan, keputusan pembelian yang nantinya akan berpengaruh pada permintaan daging ayam kampung. Hal ini sesuai dengan pendapat Kotler (2000) kebutuhan dan selera seseorang akan berubah sesuai dengan bertambahnya usia. Pembelian dibentuk oleh tahap siklus hidup keluarga, sehingga pemasar perlu memperhatikan perubahan minat pembelian yang berhubungan dengan daur siklus hidup manusia.

Variabel pendapatan berpengaruh terhadap permintaan daging ayam kampung, jika diukur pada 
tingkat kepercayaan yang ditunjukkan oleh nilai thitung $\left(\mathrm{X}_{4}\right)$ sebesar 6,576> t-tabel yaitu sebesar 1,674 yang berarti $\mathrm{H}_{0}$ ditolak dapat disimpulkan bahwa harga daging ayam kampung $\left(\mathrm{X}_{4}\right)$ di pasar tradisional Kota Surakarta secara individu berpengaruh pada tingkat kepercayaan 95\% terhadap permintaan daging ayam kampung. Variabel pendapatan berpengaruh terhadap permintaan daging ayam kampung. Hal ini karena tingkat pendapatan konsumen sangat berpengaruh terhadap permintaan daging ayam kampung. Tingkat pendapatan yang tinggi akan membuat permintaan meningkat. Menurut Sukirno (2002) pendapatan para pembeli merupakan faktor yang sangat penting dalam menentukan permintaan terhadap berbagai barang.

Variabel pendidikan berpengaruh terhadap permintaan daging ayam kampung, jika diukur pada tingkat kepercayaan yang ditunjukkan oleh nilai thitung $\left(\mathrm{X}_{5}\right)$ sebesar 1,288< t-tabel yaitu sebesar 1,674 yang berarti $\mathrm{H}_{0}$ diterima dapat disimpulkan bahwa harga daging ayam kampung $\left(\mathrm{X}_{5}\right)$ di pasar tradisional Kota Surakarta secara individu tidak berpengaruh pada tingkat kepercayaan $95 \%$ terhadap permintaan daging ayam kampung. Variabel jumlah anggota keluarga tidak berpengaruh terhadap permintaan daging ayam kampung, jika diukur pada tingkat kepercayaan yang ditunjukkan oleh nilai t-hitung $\left(\mathrm{X}_{5}\right)$ sebesar $-1,214<\mathrm{t}$-tabel yaitu sebesar 1,674 yang berarti $\mathrm{H}_{0}$ diterima dapat disimpulkan bahwa harga daging ayam kampung $\left(\mathrm{X}_{5}\right)$ di pasar tradisional Kota Surakarta secara individu tidak berpengaruh pada tingkat kepercayaan $95 \%$ terhadap permintaan daging ayam kampung. Variabel pendidikan tidak berpengaruh terhadap permintaan daging ayam kampung. Hal ini karena tingkat pendidikan tidak menentukan pemenuhan kebutuhan. Konsumen membeli daging beragam pendidikannya dari yang rendah hingga tinggi. Mereka membeli daging ayam kampung karena memang sudah kebutuhan berdasarkan kesukaan dari konsumen itu sendiri. Menurut Badudu dan Sutan (2001) preferensi akan mempengaruhi konsumen menentukan pilihan produk. Definisi preferensi adalah kecenderungan dalam memilih sesuatu dibandingkan yang lainnya karena sesuai dengannya.

\section{Uji Anova}

Uji Anova atau uji beda digunakan untuk menganalisis perbedaan karakteristik demografi konsumen terhadap permintaan daging ayam kampung pada pasar tradisional. Uji Oneway Anova terhadap harga daging ayam kampung ditunjukkan pada Tabel 3.

Perbedaan karakteristik umur $\left(\mathrm{X}_{3}\right)$ terhadap permintaan menunjukkan hasil signifikan $(\mathrm{P}<0,05)$ dengan hasil $F 2,816(0,034)$ (Tabel 4). Disimpulkan bahwa umur memberikan pengaruh terhadap permintaan daging ayam kampung di pasar tradisional Kota Surakarta. Hal ini menujukkan konsumen usia produktif lebih mendominasi dalam pembelian daging ayam kampung dibanding usia belum produktif atau usia lanjut. Menurut Alam (2007) penduduk dalam usia kerja (18 tahun keatas), baik yang bekerja maupun tidak bekerja kelompok ini bisa disebut kelompok usia produktif.

Perbedaan karakteristik pendapatan $\left(\mathrm{X}_{4}\right)$ terhadap permintaan menunjukkan hasil signifikan $(\mathrm{P}<0,05)$ dengan hasil $F$ 4,971 $(0,004)$ (Tabel 4). Disimpulkan bahwa pendapatan memberikan pengaruh terhadap permintaan daging ayam kampung di pasar tradisional Kota Surakarta. Sukirno (2002) pendapatan para pembeli merupakan faktor yang sangat penting dalam menentukan permintaan terhadap berbagai barang.

Perbedaan karakteristik pendidikan $\left(\mathrm{X}_{5}\right)$ terhadap permintaan menunjukkan hasil tidak signifikan $(\mathrm{P}>0,05)$ dengan hasil $F$ 1,801 $(0,142)$ (Tabel 4). Disimpulkan bahwa pendidikan tidak memberikan pengaruh terhadap permintaan daging ayam kampung di pasar Tradisional Kota Surakarta.Konsumen dengan pendidikan tinggi maupun rendah, tidak berpengaruh karena membeli daging merupakan kebutuhan pangan bagi konsumen yang harus dipenuhi setiap harinya.

Perbedaan karakteristik jumlah anggota keluarga $\left(\mathrm{X}_{6}\right)$ terhadap permintaan menunjukkan hasil yang tidak signifikan $(\mathrm{P}>0,05)$ denga hasil $F 0,619$ $(0,606)$ (Tabel 4). Disimpulkan bahwa jumlah anggota keluarga tidak memberikan pengaruh terhadap permintaan daging ayam kampung di pasar tradisional Kota Surakarta. Konsumen yang memiliki jumlah anggota keluarga banyak maupun sedikit mereka tetap akan membeli membeli daging ayam kampung selain untuk memenuhi kebutuhan protein hewani juga karena daging ayam kampung memiliki cita rasa yang enak untuk diolah. Hal ini sesuai dengan pendapat Suryo et al. (2012) daging ayam kampung sangat diminati masyarakat karena rasanya yang enak, gurih, tidak lembek dan rendah lemak.

\section{SIMPULAN}

Variabel umur, pendapatan, pendidikan, jumlah anggota keluarga, harga daging ayam kampung, harga daging ayam broiler, bersama-sama berpengaruh terhadap permintaan daging ayam kampung di Kota Surakarta.Variabel umur dan pendapatan secara individual berpengaruh nyata terhadap permintaan daging ayam kampung. Faktor demografis konsumen yaitu umur, pendapatan, meninjukkan perbedaan terhadap permintaan daging ayam kampung di pasar tradisional Kota Surakarta.

\section{DAFTAR PUSTAKA}

Alam, S. 2007. Ekonomi. Eksis. Jakarta.

Badan Pusat Statistik Kota Surakarta. 2016. Data Penduduk Kota Surakarta. Surakarta.

Badudu, J.S dan Z. M. Sutan. 2001. Kamus Umum Bahasa Indonesia. Pustaka Sinar Harapan. Jakarta. 
Ghozali, I. 2013. Aplikasi Analisis Multivariat dengan Program IBM SPSS 21. Universitas Diponegoro. Semarang.

Kasih, N. S., A. Jaelani dan N. Firahmi. 2012. Pengaruh lama penyimpanan daging ayam segar dalam refrigerator terhadap $\mathrm{pH}$, susut masak dan organoleptik. J Med Sains 4 (2): 154-159.

Kotler, P dan G. Armstrong. 2005. Prinsip-prinsip Pemasaran. Edisi ke-8. Erlangga. Jakarta.

Sugiyono. 2009. Metode Penelitian Kuantitatif dan Kualitatif. Alfabeta. Bandung.

Sukirno, S. 2002. Teori Mikro Ekonomi. Cetakan ke14. Rajawali. Jakarta.

Sumarwan, U. 2003. Perilaku Konsumen, Teori dan Penerapannya Dalam Pemasaran. Ghalia Indonesia. Jakarta.

Suryo, T., Yudiarti, T dan Isroli. 2012. Pengaruh pemberian probiotik sebagai aditif pakan terhadap kadar kolestrol, High Density Lipoprotein (HDL) dan Low Density Lipoprotein (LDL) dalam darah ayam kampung. Animal Agriculture Journal 1(2): 228 - 237.

Suyanto dan Nurhadi. 2004. Ekonomi untuk SMP Kelas VIII. Erlangga. Jakarta

Triyanti. 2000. Prosiding Seminar Nasional Peternakan dan Veteriner. Pusat Penelitian Peternakan Bogor. Bogor. 